\title{
norden
}

Ved Stranden 18

DK-1061 København K

www.norden.org

\section{„Pjarmað að skattaskjólum“ Norræn saga af velgengni}

Norrænt samstarf um gerð samninga við fjármálastöðvar á aflandseyjum um upplýsingaskipti um skattamál

() Norræna rádherranefndin 2014

Umbrot: Hanne Lebech

Kápumynd: Signelements

Prentun: Rosendahls-Schultz Grafisk

Upplag: 500

\section{Printed in Denmark}

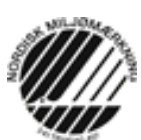

\section{Norrænt samstarf}

Norræna samstarfið er eitt umfangsmesta svæðasamstarf í heiminum. Samstarfið nær til Danmerkur, Finnlands, Íslands, Noregs og Svípjódar auk Álandseyja, Færeyja og Grænlands.

Norræna samstarfið er pólitískt, efnahagslegt og menningarlegt og skiptir miklu i evrópsku og alpjód-

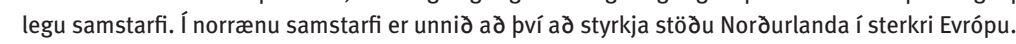

Með norrænu samstarfi er unnið að pví að efla norræna og svæðisbundna hagsmuni íalbjóðlegu

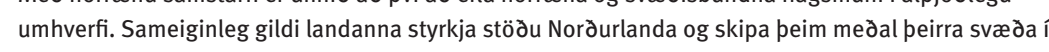
heiminum par sem nýsköpun og samkeppnishæfni er mest.

\section{Norræna ráðherranefndin}

Ved Stranden 18

DK-1061 København K

Sími (+45) 33960200

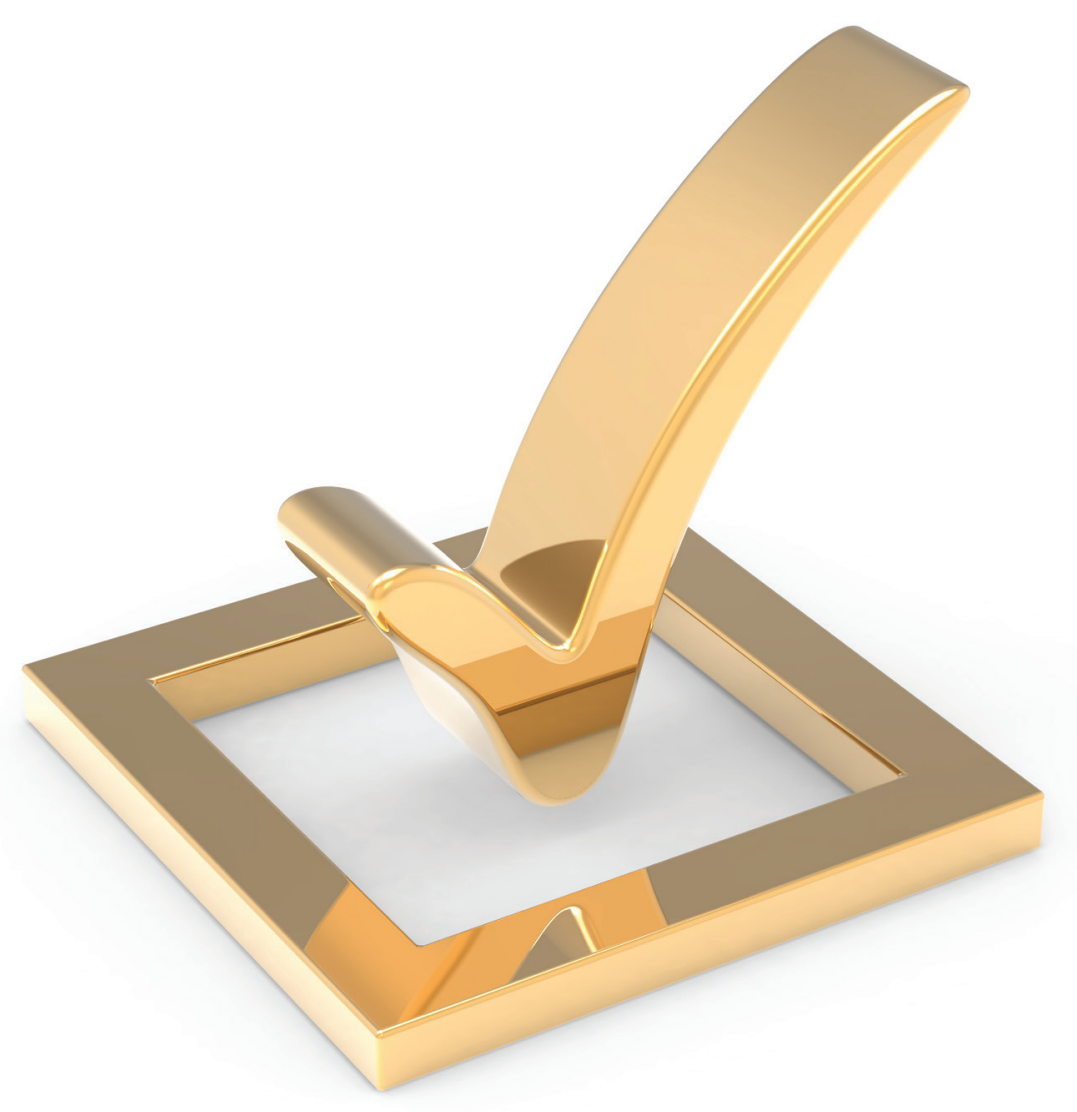




\section{8}

Guernsey $V$

Jersey $V$

2009

Caymaneyjar $V$

Bermúda $V$

Bresku Jómfrúaeyjar $\vee$

Arúba $V$

Curaçao $V$

Angvilla $V$

Turks- og Caicoseyjar $V$

Gíbraltar $V$

Cookseyjar $V$

Samóa $V$

\section{0}

San Marínó $V$

Andorra $V$

Bahamaeyjar $V$

St. Vincent og Grenadineyjar $\vee$

St. Kristófer og Nevis $V$

Sankti Lúsía V

Dominíka V

Grenada $V$

Antígva og Barbúda $V$

Mónakó $V$

Belís V

Marshalleyjar $V$

Vanuatu $V$

Líbería $V$

Montserrat $V$

Liechtenstein $V$

\section{1}

Seychelleseyjar $V$

Makaó (Kína) $V$

Kostaríka V

Barein $V$

Barbados $V$

Máritíus $V$

Úrúgvæ

\section{2}

Gvatemala $V$

Brunei $V$

Panama $V$

Jamaíka $V$

\section{3}

Botsvana $V$

Katar V

Níveeyja $V$

\section{4}

Hong Kong (Kína) $V$

Sameinuðu arabísku furstadæmin

\section{„Pjarmad ad skattaskjólum“}

Norræn saga af velgengni

Til er verkefni sem hefur skilað milljörðum króna til norrænu landanna. Verkefnið kallast fullu nafni Norrænt samstarf um gerð samninga við fjármálastöðvar á aflandseyjum um upplýsingaskipti um skattamál. Á hversdagsmáli mætti kalla pad „Pjarmað að̃ skattaskjólum“.

Hér er á ferðinni saga mikils árangurs par sem tekist hefur að breyta landslagi i alpjódlegum skattamálum varanlega. Frumkvöðlastarf og prautseigja í samstarfi undir stjórn Torstens Fensby hefur gert pað að verkum að Norðurlöndunum hefur tekist að semja um upplýsingaskipti við öll ríki heims par sem bankaleynd eəa önnur löggjöf kemur í veg fyrir innsýn í skattamál einstaklinga og fyrirtækja.

Hvergi i heiminum er neinn óhultur sem hyggst skjóta fé undan norrænum skatti. Eina undantekningin eru Sameinuðu arabísku furstadæmin en nú er verið að semja við pau.

Milljarðarnir sem streyma aftur norður á bóginn eru fé sem hvorki hefur verið gefið upp né skattlagt heldur geymt í felum erlendis. Ógreitt skattféd hefði átt að renna til velferðar okkar, umönnunar og hjúkrunar, menntunar, rannsókna og annarra framfara i norrænum samfélögum. Á sídustu öld voru skattaundanskot sjaldgæf en pað var eins og stífla brysti pegar alpjóðavæðingin hófst af alvöru á 8. og 9. áratug sídustu aldar. Fjármagn einstaklinga og fyrirtækja fór pá að streyma frjálst milli landa án pess að yfirvöld gætu nokkuð að gert.

Upp úr sídustu aldamótum, pegar hægði á aðgerðum Efnahags- og framfarastofnunar Evrópu gegn skattaskjólum, ákvádu Norðurlöndin að grípa til sameiginlegra aðgerða í peim tilgangi að bæta upplýsingaskipti um svonefnd skattaskjól. Með viðvörunarorðum OECD um sameiginleg viðurlög voru vonir bundnar við að hægt yrði að semja við örfá aflandsríki í byrjun en smám saman mætti ná til hinna rúmlega 40 skattaskjóla heims. Árangur norræna verkefnisins fór fram úr björtustu vonum. Áhrifin eru tvípætt, nú reynist auðveldara að rekja undanskotsfé og eins hafa samningarnir gert pað að verkum að menn eru farnir að vanda sig betur við skattaskýrsluna. Tímasetningin reyndist vera hárrétt. Nokkrum árum eftir að verkefnið hófst setti G20-hópurinn málefnið á oddinn í albjóðamálum og stofnaði Global Forum á árinu 2009. Nú eru Norðurlöndin ein fárra ríkja sem hafa péttriðið net samninga um upplýsingaskipti.

Enginn trúir pví að petta hefði getað gerst án norrænnar samvinnu. Löndin eru lítil og hvert um sig vega pau ekki nógu pungt við gerð slíkra samninga. Nú heldur starfið áfram í Norrænum vinnuhóp gegn alpjódlegum skattaundanskotun, NAIS, par sem lögð er áhersla á innleiðingu skattasamninganna.

Skattayfirvöld landanna ákveða sjálf framhaldið en upplýsingaskiptin gefa vísbendingu um hvernig megi hala inn eins mörgum milljónum gamalla króna og hægt er og koma í veg fyrir að nýtt fé streymi burt. Framvegis verður lögð áhersla á að bæta upplýsingaöflun í skattamálum enn frekar. Próunin stefnir í átt að aukinni sjálfvirkni og mun hún auðvelda upplýsingaskiptin enn frekar. Norsk skattayfirvöld hafa nád bestum árangri en bau hafa endurheimt u.p.b. 40 milljarða norskra króna sem skotið hafði verið undan skatti. Par í landi leggja menn áherslu á fyrirbyggjandi pátt samninganna. Nú er enginn skattsvikari óhultur. 